\title{
Lablab purpureus-A Crop Lost for Africa?
}

\author{
Brigitte L. Maass • Maggie R. Knox • S. C. Venkatesha • \\ Tefera Tolera Angessa $\cdot$ Stefan Ramme $\cdot$ \\ Bruce C. Pengelly
}

Received: 11 November 2009 / Accepted: 18 February 2010/Published online: 28 March 2010

(C) The Author(s) 2010. This article is published with open access at Springerlink.com

\begin{abstract}
In recent years, so-called 'lost crops' have been appraised in a number of reviews, among them Lablab purpureus in the context of African vegetable species. This crop cannot truly be considered 'lost' because worldwide more than 150 common names are applied to it. Based on a comprehensive literature review, this paper aims to put forward four theses, (i) Lablab is one of the most diverse domesticated legume species and has multiple uses. Although its largest agro-morphological diversity occurs in South Asia, its origin appears to be Africa. (ii) Crop improvement in South Asia is based on limited genetic diversity. (iii) The restricted research and development performed in Africa focuses either on improving forage or soil properties mostly through one popular cultivar, Rongai,
\end{abstract}

Communicated by: Desiree M. Hautea

Elaborated from a presentation at the International Symposium

"Underutilized plants for food, nutrition, income and sustainable development", 3-7 March 2008, Arusha, Tanzania; organized by ICUC, GFU, AVRDC, GlobalHort, Bioversity International, PROTA, and ISHS.

B. L. Maass · Tefera T. A. · S. Ramme

Department of Crop Sciences: Agronomy in the Tropics,

Georg-August-University Goettingen,

Grisebachstr. 6,

D-37077 Goettingen, Germany

M. R. Knox

John Innes Centre (JIC),

Colney Lane,

Norwich NR4 7UH, UK

S. C. Venkatesha

University of Agricultural Sciences,

GKVK Campus,

Bangalore 560065 Karnataka, India while the available diversity of lablab in Africa might be under threat of genetic erosion. (iv) Lablab is better adapted to drought than common beans (Phaseolus vulgaris) or cowpea (Vigna unguiculata), both of which have been preferred to lablab in African agricultural production systems. Lablab might offer comparable opportunities for African agriculture in the view of global change. Its wide potential for adaptation throughout eastern and southern Africa is shown with a GIS (geographic information systems) approach.

Keywords Cover crop $\cdot$ Dolichos $\cdot$ Forage $\cdot$ Genetic diversity - Genetic erosion - Homegarden - Hyacinth bean Landrace $\cdot$ Pulse $\cdot$ Traditional vegetable $\cdot$ Underutilized crop
B. C. Pengelly

Commwealth Scientific and Industrial Research Organisation (CSIRO): Sustainable Ecosystems, 306 Carmody Road,

St. Lucia, Qld. 4067, Australia

Present Address:

B. L. Maass $(\triangle)$

CIAT-TSBF,

ICRAF Campus, PO Box 30677-00100, Nairobi, Kenya

e-mail: b.maass@cgiar.org

Present Address:

Tefera T. A.

The University of Western Australia (M703),

35 Stirling Highway,

Crawley, WA 6009, Australia 


$\begin{array}{ll}\text { Abbreviations } \\ \text { AFLP } & \begin{array}{l}\text { Amplified fragment length polymorphisms } \\ \text { Bangladesh Agricultural Research Institute }\end{array} \\ \text { BSMRAU } & \begin{array}{l}\text { Bangabandhu Sheikh Mujibur Rahman } \\ \text { Agricultural University in Gazipur/India }\end{array} \\ \text { CSIRO } & \begin{array}{l}\text { Commonwealth Scientific and Industrial } \\ \text { Research Organisation/Australia }\end{array} \\ \text { EST } & \begin{array}{l}\text { Expressed sequence tag } \\ \text { Geographic information systems }\end{array} \\ \text { GIS } & \begin{array}{l}\text { International Institute of Tropical Agriculture/ } \\ \text { IITA }\end{array} \\ \text { ILRI } & \begin{array}{l}\text { Interia } \\ \text { International Livestock Research Institute/ }\end{array} \\ \text { IPGRI } & \begin{array}{l}\text { Kenya } \\ \text { International Plant Genetic Resources Institute/ }\end{array} \\ \text { IPSA } & \begin{array}{l}\text { Italy (now, Bioversity International) } \\ \text { Institute of Postgraduate Studies in Agriculture/ } \\ \text { Bangladesh (now, BSMRAU) }\end{array} \\ \text { RAPD } & \begin{array}{l}\text { Randomly amplified polymorphic DNA } \\ \text { University of Agricultural Sciences Bangalore, }\end{array} \\ \text { UAS } & \begin{array}{l}\text { India } \\ \text { United States Department of Agriculture }\end{array} \\ \text { USDA } & \text { Ind }\end{array}$

\section{Introduction}

So-called 'lost crops' have been appraised in a number of reviews in recent years, among them Lablab purpureus (L.) Sweet, one of traditional African vegetables (NRC 2006). Information on neglected crops such as lablab is typically scattered over a range of journals, reports, or manuscripts, many of which will probably never be published and, therefore, remain inaccessible to most researchers. Recent compilations of information promoting the 'conservation and use of underutilized and neglected crops' (e.g., the series by IPGRI of the same name; Hammer et al. 2001), however, have usually excluded lablab because the species has attracted certain attention in the science literature, often far more than other neglected crops (J. Heller, pers. comm. 2003). Despite its representation in the literature, however, it can be argued that lablab truly qualifies as 'underutilized' given its many attributes, potential uses and adaptation.

Lablab is an ancient crop and has been documented by archaeo-botanical finds in India prior to $1500 \mathrm{BC}$ (Fuller 2003) and at Qasr Ibrim in Egyptian Nubia from the 4th century AD (Clapham and Rowley-Conwy 2007). Despite its label of 'underutilized', however, substantial areas of lablab are sown in certain tropical regions, either as a sole crop or in mixed production systems. Its popularity may also be demonstrated by the large number of more than 150 local names reported by various authors and on databases (e.g., Westphal 1974; Kay 1979; MMPND
2005). Lablab is the third most important vegetable in the central and south-western parts of Bangladesh after eggplant (Solanum melongena) and taro (Colocasia spp.) and is reported to have a total production area in the region of approximately 48,000 ha (Rashid et al. 2007). However, the limited production data available suggest that yields are low. The species is largely cultivated as a systems' component of homegardens or mixed cropping schemes, whose specific contribution to the overall system is usually not recorded. It has been documented as part of traditional production systems, such as those based around irrigated agriculture in the oases of Oman (Gebauer et al. 2007), homegardens in Nepal (Gautam et al. 2008), India (Kumar and Ramakrishnan 1990; Peyre et al. 2006), Bangladesh (Mir et al. 2004), Thailand (FAO 1999), and other tropical countries (Table 1).

The prime objective of this paper is to stimulate debate and focus on a crop whose striking diversity, uses and adaptation might be lost in Africa, its cradle, as it continues to be overlooked in current farming systems research and development. We also highlight the genetic diversity of the species so it might be applied to plant improvement efforts, including those in Asia, which are currently based on limited genetic diversity. The paper focuses on recent progress in plant improvement and genetic resources based on a comprehensive review of scientific literature from the mid 1990s to the present and so builds on the previous reviews of the crop by Schaaffhausen (1963), Hendricksen and Minson (1985), Shivashankar and Kulkarni (1989), and Murphy and Colucci (1999).

This paper also brings together and builds on the insights of diversity and domestication of the species provided in a number of previous studies over the last 8 years (Pengelly and Maass 2001; Maass et al. 2005; Tefera 2006; Maass and Usongo 2007; and Venkatesha et al. 2007), and it offers new insights into the species' eco-geography based on passport data from 643 herbarium specimens and germplasm accessions collected from Africa (Ramme, 2002).

\section{Four Theses}

\section{(i) One of the most diverse domesticated legumes}

Lablab has been noted for decades as being one of the most agro-morphologically diverse (e.g., Piper and Morse 1915, Rivals 1953; Pengelly and Maass 2001; Mohan and Aghora 2006; Islam 2008) and versatile tropical legume species through its roles as pulse (also used as 'dhal'), vegetable (green bean, pod, leaf), forage/green manure, herbal medicine, and even ornamental (Adebisi and Bosch 2004; NRC 2006) and, more recently, Morris (2009) reviewed its bio-functional properties for use as pharmaceutical or nutraceutical. In Indonesia, seeds serve as raw 
Table 1 Lablab purpureus documented as a homegarden plant in different regions and countries of the world

\begin{tabular}{|c|c|c|c|c|}
\hline Country, Location & Region $^{\mathrm{a}}$ & Use & Local name [common name] & Reference \\
\hline Fiji, Naura & OCE & $\begin{array}{l}\text { Food (parts of plant other } \\
\text { than fruit) }\end{array}$ & [Hyacinth bean] & Brazil (1990) \\
\hline Papua New Guinea & OCE & $\begin{array}{l}\text { Food (parts of plant other } \\
\text { than fruit) }\end{array}$ & [Hyacinth bean] & Brazil (1990) \\
\hline Indonesia & SEA & $\begin{array}{l}\text { Vegetable, medicinal, } \\
\text { other }\end{array}$ & $\begin{array}{l}\text { Kara-kara, Komak, Kacang-kara, Kacang-bado, } \\
\text { Kacang-biduk, Kekarab }\end{array}$ & Levang and de Foresta (1991) \\
\hline \multirow[t]{2}{*}{ Java } & \multirow[t]{2}{*}{ SEA } & $\begin{array}{l}\text { Food (parts of plant other } \\
\text { than fruit) }\end{array}$ & [Hyacinth bean] & $\begin{array}{l}\text { Fernandes and Nair (1986); } \\
\text { Brazil (1990) }\end{array}$ \\
\hline & & Vegetable & Kara Andong, Kara Uceng [Hyacinth bean] & Krol (1992) \\
\hline W. Java & SEA & & Kara [Hyacinth bean; bonavista bean] & Abdoellah and Marten (1986) \\
\hline Sulawesi & SEA & Vegetable & Kacang komak & Kehlenbeck (2007) \\
\hline Philippines & SEA & $\begin{array}{l}\text { Food (parts of plant other } \\
\text { than fruit) }\end{array}$ & [Hyacinth bean] & $\begin{array}{l}\text { Fernandes and Nair (1986); } \\
\text { Brazil (1990) }\end{array}$ \\
\hline Thailand & SEA & & Thua paep & FAO (1999) \\
\hline Vietnam & SEA & Food (fruit) & Dâu ván & Hoang et al. (2008) \\
\hline Bangladesh, Gazipur & SA & & [Country bean] & Mir et al. (2004) \\
\hline Chittagong & & & & Momen et al. (2006) \\
\hline Sylhet & & Vegetable & & Uddin and Mukul (2007) \\
\hline India, NE & SA & & & $\begin{array}{l}\text { Kumar and Ramakrishnan } \\
\text { (1990) }\end{array}$ \\
\hline $\mathrm{S}+\mathrm{W}$ Tripura & & & Sim & Sankaran et al. (2007) \\
\hline W Bengal & & Vegetable & & Mitra and Pathak (2009) \\
\hline Uttaranchal & & & Sem & Kala (2005) \\
\hline Kerala & & & Aviram [Indian butter bean] & Peyre et al. (2006) \\
\hline Nepal & SA & Vegetable & Hiude simi & Subedi et al. (2006) \\
\hline Nepal, western & SA & Vegetable & Hiunde simi & Sunwar et al. (2006) \\
\hline Sri Lanka & SA & Vegetable & & Hochegger (1998) \\
\hline Yemen & WA & & & Ceccolini (2002) \\
\hline Ethiopia & SSA & Vegetable & Amora-guaya, Gerenga, Lubia bean, O-cala & Westphal (1974) \\
\hline
\end{tabular}

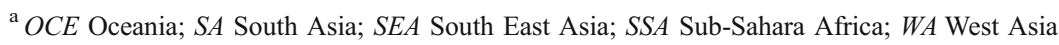

$\mathrm{b}$ various more local names listed

materials for 'tempeh', a traditional fermented food typically made from soybeans (Subagio and Morita 2008). The same authors also demonstrated that protein isolate from lablab beans has high potential as a practical food additive for improving cake quality. The degree of agromorphological diversity in the species in even a narrow geographical range is demonstrated in Nepalese homegardens where lablab is not only one of the most frequently cultivated crops but is attributed 7 and 12 named varieties in the lowland 'terai' zone (c. $100 \mathrm{~m}$ asl.) and mid-hill zone (800-1,200 m asl.), respectively (Sunwar et al. 2006). The Nepalese farmers differentiated among varieties using morphological characters such as pod shape, size and colour in conjunction with their particular seasonal adaptation. Similarly, remarkable morphological variation has also been reported throughout the entire hill region of north eastern India (Yadav et al. 2003; Sankaran et al. 2007).
Lablab also has considerable physiological diversity. Mugwira and Haque (1993) identified a range of adaptation to nutrient stresses such as acidity and low available phosphorus on two acid soils of Ethiopia. Karachi (1997) was able to show highly differential adaptation to semi-arid conditions and suitability for forage use in 17 landraces obtained from Kenyan farmers.

The versatility of its uses has resulted in comprehensive germplasm collections being assembled, with an overall total of more than 3,000 accessions worldwide (Table 2). However, this total number of accessions has many duplicates and an estimate of number of unique accessions conserved cannot be derived because of the scarcity of passport and/or characterization data.

Despite its large agro-morphological diversity in South Asia, its origin, however, appears to be African (Verdcourt 1970, 1979; Maass et al. 2005; Maass and Usongo 2007), which is the only continent where wild plants of the species 
Table 2 Summarized stock of Lablab purpureus germplasm collections ( $>10$ accessions) maintained in different countries and regions of the world

${ }^{\text {a } A V R D C}$ The World Vegetable Center, Taiwan; CSIRO Commonwealth Scientific and Industrial Research Organisation, Australia; IITA International Institute of Tropical Agriculture, Nigeria; ILRI International Livestock Research Institute, Ethiopia; USDA United States Department of Agriculture, USA

\begin{tabular}{lcl}
\hline Country, Region $^{\text {a }}$ & $\begin{array}{c}\text { Accessions } \\
\text { reported (no.) }\end{array}$ & Information source \\
\hline South America & 134 & BI (2008) \\
North America (USDA) & 52 & GRIN (2009) \\
Europe & 82 & BI (2008); IPK (2009); VIR (2009) \\
Oceania (incl. CSIRO/Australia) & 104 & BI (2008) \\
China & 410 & BI (2008) \\
Philippines & 209 & Engle and Altoveros (2000) \\
Taiwan (AVRDC) & 423 & AVRDC (2009) \\
South-East Asia (other countries) & 82 & BI (2008); NIAS (2009) \\
Bangladesh & 551 & Islam (2008) \\
India & 221 & BI (2008) \\
South Asia (other countries) & 93 & BI (2008) \\
Ethiopia (incl. ILRI) & 223 & BI (2008) \\
Kenya & 403 & BI (2008) \\
Sub-Saharan Africa (other countries; incl. IITA) & 67 & BI (2008) \\
Total & 3,054 & \\
\hline
\end{tabular}

have been recorded to occur naturally. Fuller (2003) suggested its introduction to South Asia occurred from west to east so that archaeo-botanical finds have been dated, for example, from 2000 to 1700 BC at Hallur, India's earliest Iron Age site in the state of Karnataka, to 1200-300 $\mathrm{BC}$ at the Veerapuram excavation site in the state of Andhra Pradesh.

\section{(ii) Crop improvement in South Asia, Australia and the USA based on limited genetic diversity}

Although, lablab is widespread in many Asian countries, it is not among the mainstream crops and its role in diets continues to decline in many societies. For example, lablab is disappearing from southern Japan and, while the entire reasons for this may be quite complex, it is undoubtedly related to declining relationship between traditional crops and communities, and the failure of younger generations to continue the tradition of growing heirloom varieties (D.A. Vaughan, pers. comm.). Conversely, lablab is a highly popular crop in South Asia (e.g., Haque et al. 2003; Rahman et al. 2002), where it is especially cultivated under drought-prone conditions. Genetic studies and plant improvement were conducted at Tamil Nadu Agricultural University in Coimbatore, India since the 1930s (e.g., Rangaswami Ayyangar and Krishnan Nambiar 1935) resulting in a number of cultivars being developed. At the University of Agricultural Sciences (UAS) Bangalore, India, several improved cultivars have been developed by selecting for desirable traits in segregating populations (M. Byre Gowda, pers. comm.). The most widely distributed Australian cultivars, however, resulted from research towards forage improvement (Whitbread and Pengelly 2004). This program also endeavored to combine traits of the successful, wide-spread forage cv. Rongai with an
African wild, perennial germplasm accession, which led to the release of cv. Endurance (Liu 1998). While the Australian improvement program has been discontinued, a lablab forage cultivar, cv. Rio Verde, has recently been released in Texas, USA (Smith et al. 2008).

The current most active lablab improvement programs for food, however, probably exist in India (e.g., Mahadevu and Byre Gowda 2005; Girish and Gowda 2009) and Bangladesh (e.g., Alam and Newaz 2005; Arifin et al. 2005). More than 30 improved lablab varieties have been produced at various Indian institutions since breeding began (Gopalakrishnan 2007). In Coimbatore, India, the photo-insensitive, ultra-short-duration vegetable lablab, CoLT 22/1, commences flowering at 40-42 days after sowing, and enables the harvesting of green vegetable pods as early as 48 days after sowing so enabling use throughout the year (Veerabadhiran et al. 2001). Byre Gowda (pers. comm.) from UAS Bangalore, India, recently succeeded in breeding the high-yielding, photo-insensitive cultivar HA-4.

There are also major plant breeding programs at Bangladesh Agricultural University in Mymensingh (e.g., Alam and Newaz 2005; Nahar and Newaz 2005) and at Bangabandhu Sheikh Mujibur Rahman Agricultural University in Gazipur, India (BSMRAU; formerly, IPSA, Institute of Postgraduate Studies in Agriculture) (Arifin et al. 2005). Two photo-insensitive lines have recently been bred and released as year-round cultivars, cvs. IPSA Seam-1 and IPSA Seam-2 (Rokhsana et al. 2006). These can be grown during both the hot/dry and humid/cooler seasons with flowering in both cultivars commencing between 45 and 60 days after sowing. This compares positively with the traditional photo-sensitive landraces 
that flower 2-6 months after sowing and are only grown during the hot/dry winter season. Lablab plant improvement programs are also underway in China (e.g., Tian et al. 2005; Xi and Tang 2006); however, information has proven difficult to access.

The afore-mentioned plant breeding successes illustrate most Asian activities targeting vegetable or pulse improvement, where the most important goals appear to be the development of short-duration, determinate, bushy types that are insensitive to photoperiod, fairly homogeneous and pestresistant (e.g., Ramasamy et al. 1990; Peng et al. 2001; Sultana et al. 2001; Rahman et al. 2002; Adebisi and Bosch 2004). To support these and other plant improvement objectives, genetic maps containing molecular and morphological markers have been constructed from different mapping populations (Konduri et al. 2000; Yuan et al. 2009) or improved by comparative mapping with mungbean (Vigna radiata) (Humphry et al. 2002). As a consequence of the historical interest in the crop and the focus on plant improvement, relatively large collections of landraces and other genetic stocks have been assembled in a number of institutions (Table 2). Several of these collections have provided the basis for various molecular studies of diversity (Table 3) that have helped to understand the genetic patterns of diversity of this crop.

Despite the impressive agro-morphological variation available, particularly in southern Asia, it appears that lablab in that region is genetically less diverse than material from Africa. Sultana et al. (2000) revealed that the 20 landraces from Bangladesh studied by RAPD markers were genetically similar and more related to most of the approximately 60 accessions received from CSIRO, Australia of other Asian origins than to those from diverse origins in Africa. Similarly, Venkatesha et al. (2007) showed that 62 southern Indian landraces analyzed either by AFLP or EST markers only exhibited narrow genetic diversity. When these Indian landraces were compared to the very significant genetic variation within the core collection proposed by Pengelly and Maass (2001), the limited genetic diversity available in the landraces collected from southern India became even more apparent (Fig. 1). In a molecular diversity assessment applying AFLP markers (Fig. 2), Tefera (2006) showed, on the other hand, that East African landraces were fairly distinct from the proposed core collection that was chosen to represent both agro-morphological variation and a broad range of geographical origins (Pengelly and Maass 2001). Accordingly, these newly collected East African landraces could even genetically expand the proposed core collection. The recognition of limited genetic diversity available in Indian indigenous landraces and in Indian plant improvement programs has led Mahadevu and Byre Gowda (2005) to initiate the addition of 'exotic' germplasm sourced from the USDA-held collection to their breeding program at UAS Bangalore.

\section{(iii) Limited research and development in Africa}

In contrast to South Asia, wild, undomesticated lablab has been found to occur naturally in several African countries (Verdcourt 1970, 1979), and both the wild types and domesticated African landraces have been shown to be genetically diverse (e.g., Liu 1996; Maass et al. 2005; Tefera 2006). Lablab has been a traditional crop in eastern Africa (Westphal 1974; Maundu et al. 1999) although its use has dramatically decreased in recent years (Maundu et al. 1999; Ngailo et al. 2003). In an assessment of traditional knowledge about land use along a humidity gradient in Arumeru district of Tanzania, Ngailo et al. (2003) found that, in the sub-humid villages, lablab, as a field crop, was cultivated on about $10 \%$ of the land during the 1930 s, but its use had decreased to almost nothing by 2000 (Fig. 3). Despite this decline, however, lablab appears to persist as a garden crop (rather than a field crop) in eastern and southern Africa; and recent market surveys from eastern Africa suggest that there is a high demand (and subsequently a good price) for lablab in Kenya (Ngailo et al. 2003).

There is almost no ongoing lablab research in Africa, except for programs focusing on improving soil properties by using green-manure/forage crops, such as in maizebased systems of Kenya (Mureithi et al. 2003; Cheruiyot et al. 2007; Lelei et al. 2009), Malawi (Sakala et al. 2004) and Nigeria (e.g., Ibewiro et al. 2000; Amodu et al. 2004; Gbaraneh et al. 2004; Rahman and Ogungbile 2006), or sorghum- and millet-based systems in the semi-arid tropics of Mali (Kouyaté et al. 2000). Almost all of these African initiatives have included and continue to include one popular late-maturing forage cultivar, cv. Rongai (Makembe and Ndlovu 1996; Fischler and Wortmann 1999; Haque and Lupwayi 2000; Wortmann et al. 2000; Shehu et al. 2001; Mureithi et al. 2003; Amodu et al. 2004; Nworgu and Ajayi 2005; Nyambati et al. 2006; Abeke et al. 2007; Ojiem et al. 2007; Abeke et al. 2008; Mubiru and Coyne 2009) and, as a result, the potential role of the species as a pulse or vegetable in Africa is likely to be severely underestimated. Only recent work at ILRI in Ethiopia and CSIRO in Australia (Pengelly and Maass 2001) and, subsequently, in southern Africa (Whitbread and Pengelly 2004) explored a much larger range of accessions for feed and food and identified germplasm, which was well adapted to drier climates and crop use. Similarly, Ewansiha et al. (2007) at IITA in Nigeria evaluated almost 50 germplasm accessions largely acquired from USDA for the dual purpose of feed and food. They identified accessions with good grain and forage yields of high potential for use in the cereal-legume livestock systems in the moist savannah zone of West Africa. 
Table 3 Overview of molecular studies performed on Lablab purpureus in chronological order

Germplasm sources and main objectives ${ }^{\mathrm{a}}$

Method $\quad$ Reference
applied $^{\mathrm{b}}$

CSIRO: 40 accessions for germplasm characterization

\begin{tabular}{|c|c|}
\hline RAPD & Liu (1996) \\
\hline RFLP, RAPD & Konduri et al. (2000) \\
\hline RAPD & Sultana et al. (2000) \\
\hline RFLP & Humphry et al. (2002) \\
\hline SSR & Wang et al. (2004) \\
\hline AFLP & Maass et al. (2005) \\
\hline RAPD & Tian et al. (2005) \\
\hline RAPD & Gnanesh et al. (2006) \\
\hline AFLP & Tefera (2006) \\
\hline RAPD & $\mathrm{Xi}$ and Tang (2006) \\
\hline AFLP, SSR & Venkatesha et al. (2007) \\
\hline SSR & Wang et al. (2007) \\
\hline AFLP & Patil et al. (2009) \\
\hline RAPD & Sujithra et al. (2009) \\
\hline RAPD & Yuan et al. (2009) \\
\hline AFLP, SSR & $\begin{array}{l}\text { Tariqul Islam (BARI, Bangladesh) PhD thesis in } \\
\text { process }\end{array}$ \\
\hline AFLP, SSR & $\begin{array}{l}\text { Allan Shivachi (Moi Univ., Eldoret, Kenya) MSc } \\
\text { thesis in process }\end{array}$ \\
\hline
\end{tabular}

Mapping population from cross of two CSIRO accessions

Bangladesh/Japan germplasm + CSIRO (c. 60 accessions) for germplasm characterization

Mapping population for comparative mapping with mungbean

(Vigna radiata)

USDA: $>30$ germplasm accessions

CSIRO: 103 accessions for germplasm characterization

11 varieties from Hunan province

12 landraces from southern India for characterization

Mostly core collection (28 accessions) + Tanzanian landraces for germplasm characterization

[information inaccessible due to language of publication]

62 landraces collected from southern India, compared to some core collection accessions

USDA: 47 accessions for germplasm characterization and phylogenetic analysis SSR

40 accessions from India

AFLP

10 insect-tolerant or -susceptible landraces from India

Mapping population from cross of two Chinese accessions

Germplasm collection from AVRDC + Bangladesh c. 200 accessions for germplasm characterization

Germplasm from Genebank of Kenya for germplasm characterization

${ }^{a}$ AVRDC The World Vegetable Center/Taiwan; BARI Bangladesh Agricultural Research Institute; CSIRO Commonwealth Scientific and Industrial Research Organisation/Australia; USDA United States Department of Agriculture

${ }^{\mathrm{b}} A F L P$ amplified fragment length polymorphism; RAPD randomly amplified polymorphic DNA; RFLP restriction fragment length polymorphism; SSR simple sequence repeats

A small number of studies (Fischler and Wortmann 1999; Mureithi et al. 2003; Nyende and Delve 2004; Odunze et al. 2004; Tefera 2006) have attempted to address with farmers the issue of acceptability of lablab, its varieties and potential uses. These are key initiatives if lablab use is to be expanded as it is, or has become, an unknown species and crop to most farmers and rural communities. When performing a participatory evaluation among various lablab accessions with a variety of panelists, Tefera (2006) found that many were neither accustomed to production nor to consumption
Fig. 1 Principal component analysis from 151 AFLP markers of 53 Lablab purpureus accessions indicating narrow genetic diversity of southern Indian landraces (UAS cluster) maintained at UAS Bangalore as opposed to members from a core collection proposed by Pengelly and Maass (2001) (Modified from Venkatesha et al. 2007)

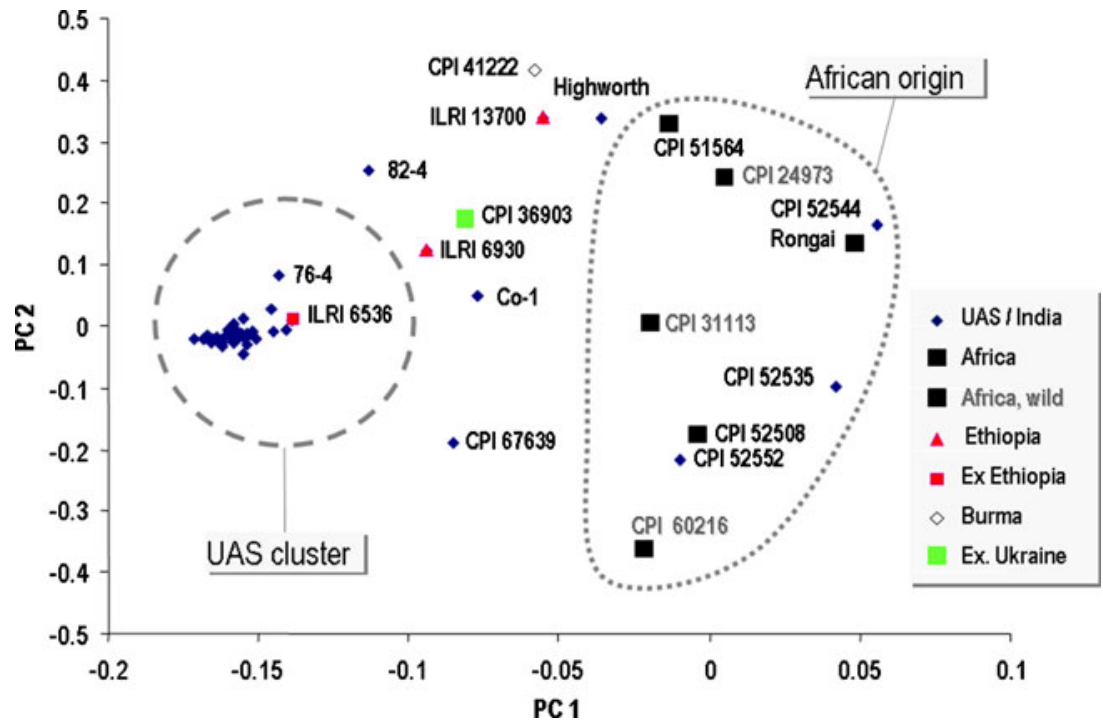


Fig. 2 Dendrogram of the diversity among 33 Lablab purpureus accessions assessed by AFLPs (Amplified Fragment Length Polymorphism), applying UPGMA (Unweighted Pair Group Arithmetic Means Algorithm), and hierarchical cluster analysis. Core collection accessions proposed by Pengelly and Maass (2001) in dotted lines, two ILRI-accessions of subsp. uncinatus in dashed lines; eastern African landraces in bold lines; TZA = Tanzania. (Modified from Tefera 2006)

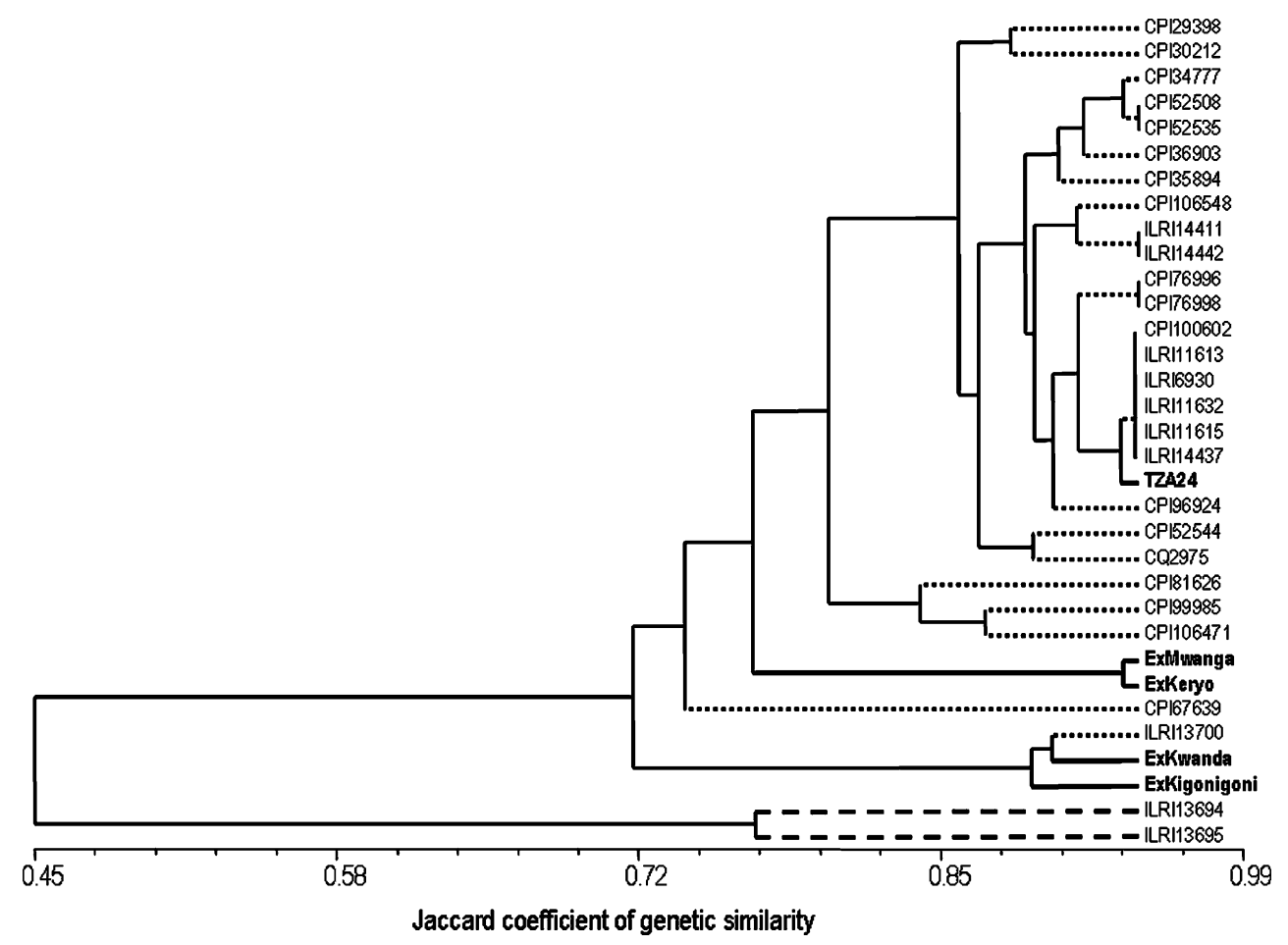

of the crop although they appreciated the quality of some accessions and the substantial difference in pod characteristics existing among them. During an organoleptic taste assessment, some of the panelists even questioned if the pods of certain accessions came from snap bean (Phaseolus vulgaris) varieties (Tefera 2006).

With the exception of the study by Tefera (2006) in Tanzania and M.G. Kinyua's (pers. comm.) recent inception of a plant improvement program at Moi University, Kenya, there are no reports of ongoing research on improving lablab as a food for Africa.

\section{Sub-humid: Ng'iresi and Olgilai villages}

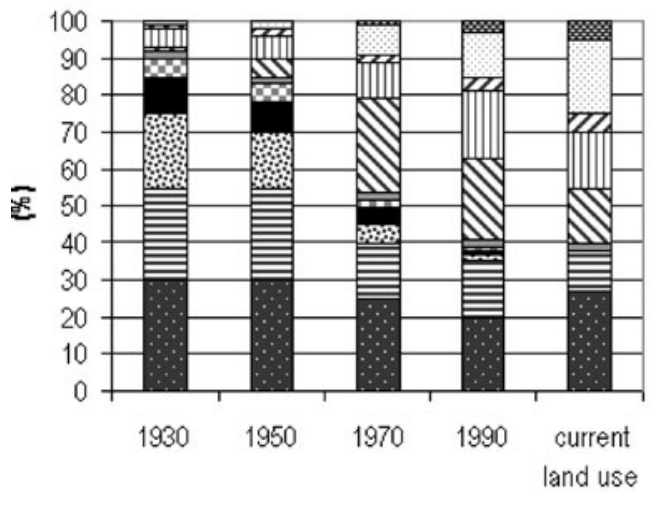

Farmers age group (approx. year of birth)

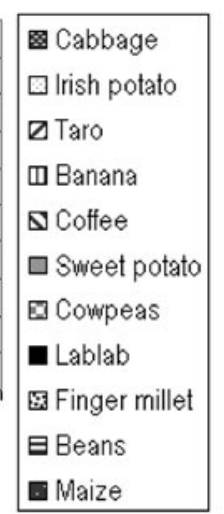

a

Fig. 3 In four villages of Arumeru district, Tanzania, 30 farmers of different approximate age groups were interviewed about land use changes along a transect from (a) sub-humid to (b) semi-arid; this was
The traditional diversity of lablab in Africa is undoubtedly under threat of genetic erosion. Given its unique and important genetic resource for any potential improvement program, be it in Asia or Africa, a substantial conservation program needs urgently to be undertaken.

(iv) Outstanding adaptation to drought

Lablab is especially adapted to drought (e.g., Maundu et al. 1999) and has been reported to have better drought tolerance than common beans (Phaseolus vulgaris) or cowpea (Vigna unguiculata) (Piper and Morse 1915). When Keller et al. (2006) surveyed diversity of indigenous vegetables in eastern

\section{Semi-arid: Moshono and Kiserian villages}
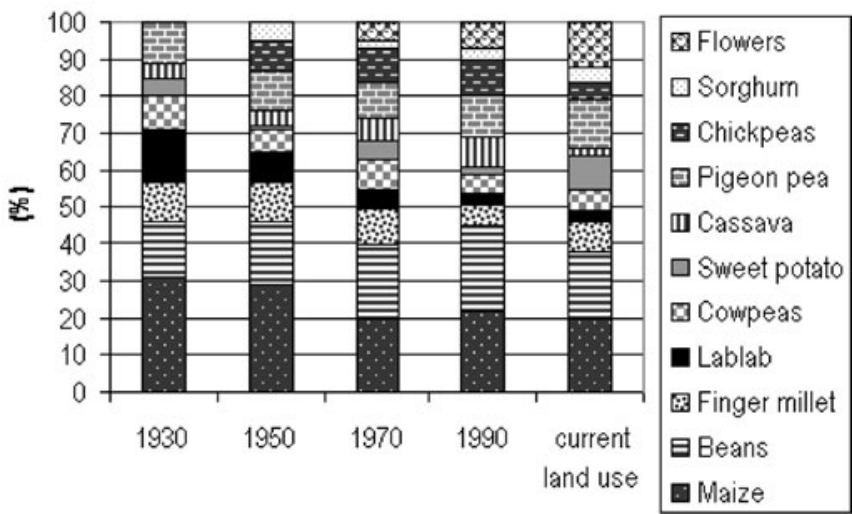

Farmers age group (approx. year of birth)

b

compared to records and a current assessment. (Derived from Ngailo et al. 2003) 
Tanzania, lablab was mostly recorded from the dryer regions and was cultivated in 9 from 10 villages surveyed in the Kongwa district (Keller 2004). Ngailo et al. (2003) also showed that farmers in northern Tanzania perceived the portion of their land cropped with lablab to remain almost the same in two semi-arid villages over a period of about 70 years, while it decreased drastically in two sub-humid villages over the same period (Fig. 3). According to data compiled by Cook et al. (2005), forage lablab is best adapted to annual rainfall regimes of $650-3,000 \mathrm{~mm}$ although it can be used as a forage in regions with rainfall of $<500 \mathrm{~mm}$ provided seedlings can be established. However, lablab does drop leaves during prolonged dry periods. Cook et al. (2005) also maintained that lablab is able to extract soil water from at least $2 \mathrm{~m}$ depth, even in heavy-textured soils. Muchow (1985) showed lablab cv. Highworth to be among the more drought-tolerant crops, when comparing its grain yield with those of soybean (Glycine max) and different Vigna species in semi-arid southern Australia. This was confirmed by a study of the relative shoot drought tolerance of major crops grown in the semi-arid tropics, where survival at the seedling stage was compared (Singh and Matsui 2002). Only seedlings of some cowpea accessions and lablab survived in reasonable percentages, even 19 days after terminating watering.

Drought is an important production constraint in the West African savannah zone, where drought stress in both the seedling and terminal growth stages results in low grain and fodder yields. Nworgu and Ajayi (2005) showed that lablab was the most drought-tolerant species in a comparison of various tropical forage legumes evaluated in South-Western Nigeria. Despite occasional reports of only moderate drought tolerance, such as that by Abdel-Wahab et al. (2002) who concluded from nodulation experiments on different soil types in Egypt that the one lablab accession studied was only tolerant to moderate levels of drought, there is overwhelming evidence that there is both strong drought tolerance and considerable diversity in drought tolerance within the species. For example, Ewansiha and Singh (2006) reported significant variation in drought tolerance of seedlings in lablab and cowpea, with the number of days to $100 \%$ plant death in lablab and cowpea seedlings ranging from 19 to 31 and 21 to 30 , respectively.

\section{Prospects}

Mapping the Potential of Lablab in Africa

The probability of occurrence and potential use of lablab throughout eastern and southern Africa can be estimated by using passport data from a range of germplasm accessions and herbarium specimens as input into the FloraMap ${ }^{\circledR}$ program (Jones and Gladkov 1999; Jones et al. 2002), and by subsequently calculating and mapping the distribution probability based on climatic similarities. The resulting map (Fig. 4a) is in contrast to that generated by a database on tropical forages and derived primarily from known adaptation of widespread forage cultivars, such as cvs. Rongai or Highworth (Fig. 4b; Cook et al. 2005). While the tropical forages mapping suggests that large parts of eastern Africa are only marginally suited to the species, the analysis using passport data indicated that many accessions were collected from precisely some of those regions defined as "marginally a

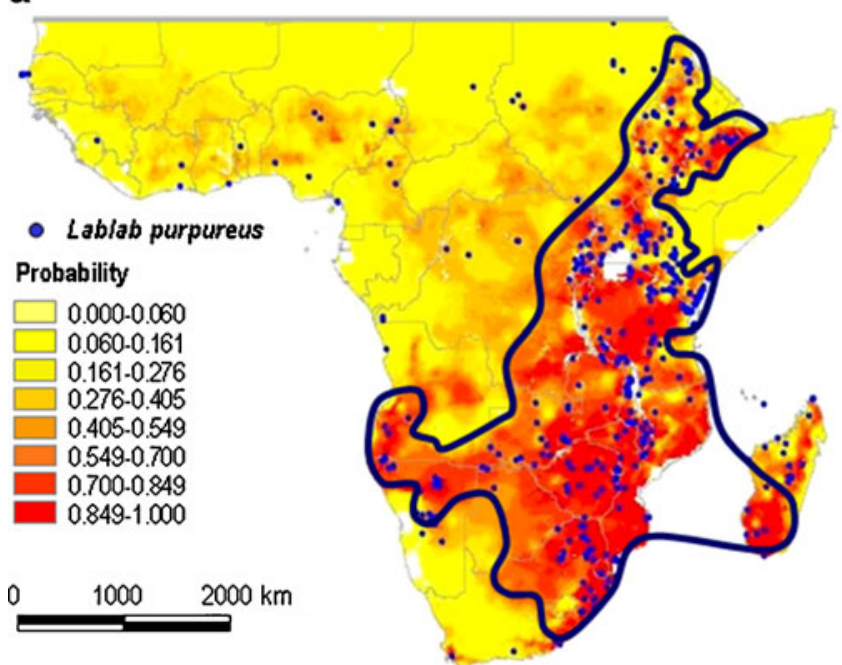

Fig. 4 Maps of ecogeographic surveys of Lablab purpureus, predicting (a) high probability of occurrence of the species, based on 643 herbarium specimens and germplasm accessions by applying FloraMap ${ }^{\circledR}$

\section{b}

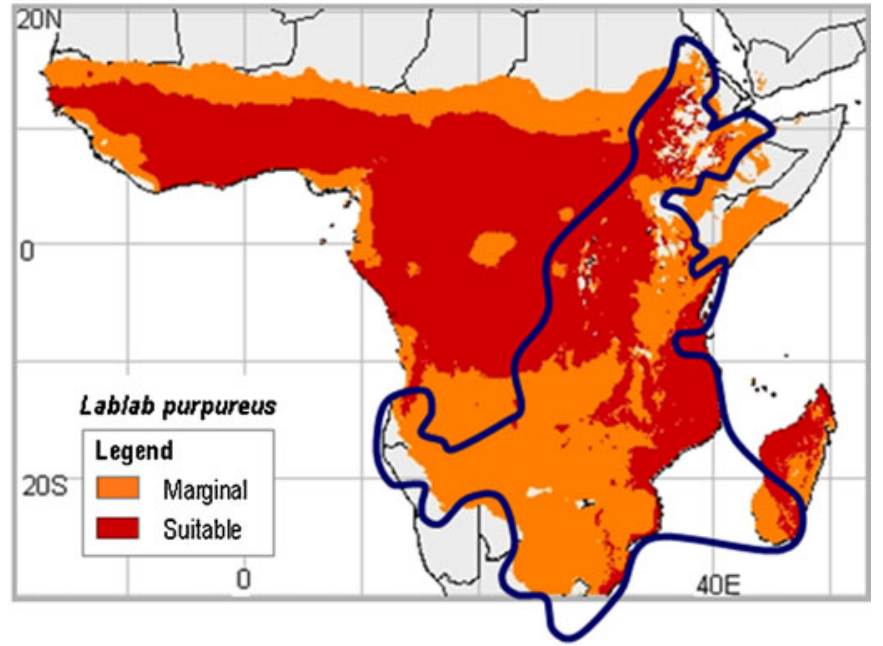

(Modified from Ramme 2002); or (b) high and marginal suitability of the crop from the Tropical Forages database (Cook et al. 2005). The line includes the high probability area generated by FloraMap 
suited" (Fig. 4a). Such divergent outcomes from GIS analyses can be expected when different ecotypes of a species are included (Jones and Gladkov 1999), as is the case here. The integrity of the divergence between the adaptation maps based on different ecotypes is supported by on-theground adaptation studies in southern Africa, where cvs. Rongai and Highworth were deemed to be unsuitable due to long vegetative phases that made them prone to early frosts or drought and impeded seed production (Maass et al. 2003; Whitbread and Pengelly 2004). Overall, the two maps demonstrate the wide potential range of adaptation for this species in Africa, depending both on specific genotypes (cultivars) and its purpose of use(s).

Few germplasm or herbarium collections originated from West and Central Africa. However, it would be expected that the species be adapted over a large proportion of that region given its rainfall and latitude. Widespread adaptation in West and Central Africa is supported by the forage accession analyses' prediction of adaptation in the region (Fig. 4b).

\section{Future Opportunities}

The provocative title on whether or not $L$. purpureus is a crop lost for Africa aims to stimulate consideration of this versatile, variable and adaptable crop resource and avoid its loss. While the current initiatives to develop this underutilized plant for food and feed in Africa continue to be founded on a very narrow genetic base, and often on plant types selected for forage rather than pulses or vegetables, there is every reason for concern that known and existing biodiversity, which may be more suited to Africa and its range of climates, is being overlooked.

Adebisi and Bosch (2004) summarized that lablab has considerable promise as a crop species because its grain yields can be higher than those of cowpea and its spectrum of adaptability to differing ecological conditions is wider than for any other leguminous plant. However, not enough is known about adaptation to drought across the species (Ewansiha and Singh 2006). Even less information exists about the physiological mechanisms of that adaptation. The history, success and failure of lablab evaluation in various African environments, either as a crop or forage, have clearly been based on narrow genetic diversity and a few commercial cultivars, some of which were initially selected for their forage value only. Basing decisions on the potential value of the crop in Africa on results from this limited genetic base will undoubtedly lead to the risk that the species as a whole may be discarded (Maass et al. 2003). A wider range of diversity exists and is available from the world's genebanks, including African indigenous materials. And this wider range of germplasm needs to be evaluated in future work. This may not only provide new insights into the potential role of lablab, in semi-arid regions in particular, but such an approach may also aid in ensuring that indigenous germplasm is conserved.

Due to its drought tolerance, lablab might offer comparable opportunities for African agriculture in the view of global change. The IPCC (2007) report indicates that many semi-arid areas, including southern Africa, will suffer a decrease in water resources due to climate change. Thornton et al. (2002) mapped the possible changes in production systems over sub-Saharan Africa and came to the conclusion that some of the existing cropping systems may decrease in area.

The mutual benefit and potential collaborations arising from the exchange of materials and knowledge between African and Asian researchers will hopefully have been stimulated during the First International Lablab Meeting near Arusha, Tanzania, in March 2008. Improved, high-yielding cultivars from drought-prone areas in India could contribute to African food security in regions with similar climates. Genetically distant African landraces may offer to the South Asian breeding programs new sources for pest and disease resistance together with other important traits. Collecting special purpose germplasm from semi-arid regions, such as in Namibia, where the wild $L$. purpureus subsp. uncinatus var. rhomboïdeus has been recorded (Verdcourt 1970) and which has never been included in any screening program, may add needed traits for future breeding programs.

Acknowledgements This paper, together with an international meeting to stimulate collaborative activities among African and Asian researchers, was generously supported by the Kirkhouse Trust, UK. S.C. Venkatesha's $\mathrm{PhD}$ thesis research is greatly benefiting from supervisions by Dr. T.H.N. Ellis (JIC, UK), Dr. P.H. Ramanjini Gowda and Dr. M. Byre Gowda (both UAS Bangalore, India). The following are the affiliations for personal communications: Dr. M. Byre Gowda, UAS, GKVK Campus, Bangalore 560 065, Karnataka, India, e-mail: mbyregowda@rediffmail.com; Prof. Dr. J. Heller, University of Applied Sciences RheinMain, Rüdesheimer Str. 5, 65366 Geisenheim, Germany, e-mail: joachim.heller@hs-rm.de; Prof. Dr. M.G. Kinyua, Moi University, PO Box 1125-30100, Eldoret, Kenya, e-mail: mgkinyua@africaonline.co.ke; Dr. D.A. Vaughan, National Institute of Agrobiological Sciences, Kannondai 2-1-2, Tsukuba 305-8602, Ibaraki, Japan, e-mail: duncan@affrc.go.jp.

Open Access This article is distributed under the terms of the Creative Commons Attribution Noncommercial License which permits any noncommercial use, distribution, and reproduction in any medium, provided the original author(s) and source are credited.

\section{References}

Abdel-Wahab AM, Shabeb MSA, Younis MAM (2002) Studies on the effect of salinity, drought stress and soil type on nodule activities of Lablab purpureus (L.) Sweet (Kashrangeeg). J Arid Environ 51:587-602 
Abdoellah OS, Marten GG (1986) The complementary roles of homegardens, upland fields, and rice fields for meeting nutritional needs in West Java. In: Marten GG (ed) Traditional Agriculture in Southeast Asia: a human ecology perspective, Westview Press, Boulder, Colorado, USA, pp 293-325

Abeke FO, Ogundipe SO, Sekoni AA, Dafwang II, Adeyinka IA, Oni OO, Abeke A (2007) Growth and subsequent egg production performance of Shika-brown pullets fed graded levels of cooked Lablab purpureus beans. Pak J Biol Sci 10(7):1056-1061

Abeke FO, Ogundipe SO, Sekoni AA, Dafwang II, Adeyinka IA, Oni OO, Abeke A (2008) Effect of dietary levels of cooked Lablab purpureus beans on the performance of broiler chickens. Asian J Anim Vet Adv 3(1):42-49

Adebisi AA, Bosch CH (2004) Lablab purpureus (L.) Sweet. In: Grubben GJH, Denton OA (eds) Plant Resources of Tropical Africa (PROTA), no. 2, vegetables. PROTA Foundation, Wageningen, The Netherlands / Backhuys, Leiden, The Netherlands / CTA, Wageningen, The Netherlands, pp 343-348

Alam MM, Newaz MA (2005) Combining ability for flower and pod characters of lablab bean under two sowing environments. Asian J Plant Sci 4(6):603-607

Amodu JT, Adeyinka IA, Lakpini CAM (2004) Response of lablab varieties to farmyard manure in the northern Guinea Savanna of Nigeria. Trop Grassl 38:186-191

Arifin MS, Baque MA, Islam SMAS, Hossain MM, Karim AJMS (2005) Influence of NPK and cowdung on the yield performance of IPSA SEAM-3. Int J Sustain Agric Technol 1(6):69-75

AVRDC (The World Vegetable Center) (2009) AVRDC Vegetable Genetic Resources Information System (AVGRIS), Shanhua, Taiwan. [Online 11.11.2009 from: http://203.64.245.173/avgris/]

BI (Bioversity International) (2008) Bioversity directory of germplasm collections, Rome, Italy. [Online 13.02.2008 from: http://www. bioversityinternational.org/Information Sources/Germplasm Databases/Germplasm_Collection_Directory/index.asp]

Brazil MA (1990) A list of herbaceous and woody plants grown in home gardens world-wide. In: Landauer K, Brazil M (eds) Tropical home gardens. The United Nations University, Tokyo, $214 \mathrm{pp}$

Ceccolini L (2002) The homegardens of Soqotra island, Yemen: an example of agroforestry approach to multiple land-use in an isolated location. Agrofor Syst 56(2):107-115

Cheruiyot EK, Mwonga SM, Mumera LM, Macharia JK, Tabu IM, Ngugi JG (2007) Rapid decay of dolichos (Lablab purpureus (L.) Sweet) residue leads to loss of nitrogen benefit to succeeding maize (Zea mays L.). Aust J Exp Agric 47:1000-1007

Clapham A, Rowley-Conwy P (2007) New discoveries at Qasr Ibrim, Lower Nubia. In: Cappers R (ed) Fields of change: progress in African archaeobotany. Barkhuis \& Groningen University Library, Groningen, The Netherlands, pp 157-164

Cook BG, Pengelly BC, Brown SD, Donnelly JL, Eagles DA, Franco MA, Hanson J, Mullen BF, Partridge IJ, Peters M, Schultze-Kraft R (2005) Tropical forages: an interactive selection tool [CD-ROM], CSIRO, DPI\&F(Qld), CIAT and ILRI, Brisbane, Australia. [Online 13.02.2008 from: http://www.tropical-forages.org]

Engle LM, Altoveros NC (eds) (2000) Collection, conservation and utilization of indigenous vegetables: Proc. of a workshop, AVRDC, Shanhua, Tainan, Taiwan, 16-18 August 1999. Asian Vegetable Research and Development Center (AVRDC), Shanhua, Taiwan, ROC, $142 \mathrm{pp}$

Ewansiha SS, Singh BB (2006) Relative drought tolerance of important herbaceous legumes and cereals in the moist and semi-arid regions of West Africa. J Food Agr Environ 4(2):188 190

Ewansiha SU, Chiezey UF, Tarawali SA, Iwuafor ENO (2007) Potential of Lablab purpureus accessions for crop-livestock production in the West African savanna. J Agric Sci 145:229 238
FAO (1999) The vegetable sector in Thailand: a review. FAO: regional office for Asia and the Pacific, Bangkok, Thailand. [Online 10.04.2008 from: http://www.tistr.or.th/RAP/publication/1999/ 1999_38_web_high.pdf]

Fernandes ECM, Nair PKR (1986) An evaluation of the structure and function of tropical homegardens. Agric Syst 21:279-310

Fischler M, Wortmann CS (1999) Green manures for maize-bean systems in eastern Uganda: agronomic performance and farmers' perceptions. Agrofor Syst 47:123-138

Fuller DQ (2003) African crops in prehistoric South Asia: a critical review. In: Neumann K, Butler A, Kahlheber S (eds) Food, fuel, fields-progress in African archaeobotany, Heinrich-BarthInstitut, Köln, Germany. Africa Praehistorica 15:239-271

Gautam R, Sthapit B, Subedi A, Poudel D, Shrestha P, Eyzaguirre P (2008) Home gardens management of key species in Nepal: a way to maximize the use of useful diversity for the well-being of poor farmers. Plant Genet Resour 7:142-153

Gbaraneh LD, Ikpe FN, Larbi A, Wahua TAT, Torunana JMA (2004) The influence of lablab (Lablab purpureus) on grain and fodder yield of maize (Zea mays) in a humid forest region of Nigeria. $\mathbf{J}$ Appl Sci Environ Manage 8(2):45-50

Gebauer J, Luedeling E, Hammer K, Nagieb M, Buerkert A (2007) Mountain oases in northern Oman: an environment for evolution and in situ conservation of plant genetic resources. Genet Resour Crop Evol 54:465-481

Girish G, Gowda MB (2009) Inheritance of qualitative characters in Dolichos bean Lablab purpureus L. Sweet. Environ Ecol 27 (2): $571-580$

Gnanesh BN, Reddi Sekhar M, Raja Reddy K (2006) Genetic diversity analysis of field bean (Lablab purpureus L.Sweet) through RAPD markers. Poster presented at BARC Golden Jubilee \& DAE-BRNS life sciences symposium 2006 on trends in research and technologies in agriculture and food sciences at Bhabha Atomic Research Centre (BARC), Mumbai, India, 18-20 Dec 2006. Book of Abstracts, p 78

Gopalakrishnan TR (2007) Legume vegetables. In: Vegetable crops. Horticulture science series 4. New India Publishing Agency, New Delhi, India, chapter 8, pp 169-198

GRIN (Genetic Resources Information Network) (2009) National plant germplasm system, Beltsville, MD, USA. [Online 11.11.2009 from: $\mathrm{http}: / /$ www.ars-grin.gov/cgi-bin/npgs/acc/query.pl]

Hammer K, Heller J, Engels J (2001) Monographs on underutilized and neglected crops. Genet Resour Crop Evol 48:3-5

Haque I, Lupwayi NZ (2000) Nitrogen fixation by annual forage legumes and its contribution to succeeding wheat in the Ethiopian highlands. J Plant Nutr 23(7):963-977

Haque ME, Rahman M, Rahman MA, Roy AK, Sikdar B (2003) Lablab bean based intercropping system in northwest region of Bangladesh. Pak J Biol Sci 6(10):948-951

Hendricksen RE, Minson DJ (1985) Lablab purpureus - a review. Herb Abstr 55(8):215-228

Hoang SV, Baas P, Kessler PJA (2008) Uses and conservation of plant species in a national park - a case study of Ben En, Vietnam. Econ Bot 62(4):574-593

Hochegger K (1998) Farming like the forest-traditional home garden systems in Sri Lanka. Margraf Verlag, Weikersheim, 203 pp

Humphry M, Konduri V, Lambrides C, Magner T, McIntyre C, Aitken E, Liu C (2002) Development of a mungbean (Vigna radiata) RFLP linkage map and its comparison with lablab (Lablab purpureus) reveals a high level of colinearity between the two genomes. Theor Appl Genet 105(1):160-166

Ibewiro B, Sanginga N, Vanlauwe B, Merckx R (2000) Nitrogen contributions from decomposing cover crop residues to maize in a tropical derived savanna. Nutr Cycl Agroecosyst 57(2):131-140

IPCC (Intergovernmental Panel on Climate Change) (2007) Summary for Policymakers. In: "Climate Change 2007"-the IPCC fourth 
assessment report (AR4). [Online 20.02.2008 from: http://www. ipcc.ch/press/index.htm]

IPK (Leibniz Institute of Plant Genetics and Crop Plant Research) (2009) Genebank information system of the IPK Gatersleben, Germany. [Online 11.11.2009 from: http://gbis.ipk-gatersleben. de/gbis_i/]

Islam MT (2008) Morpho-agronomic diversity of hyacinth bean (Lablab purpureus (L.) Sweet) accessions from Bangladesh. Plant Genet Resour News1 156:72-77

Jones PG, Gladkov A (1999) FloraMap - a computer tool for predicting the distribution of plants and other organisms in the wild. Version 1. CIAT CD-ROM Series, Cali, Colombia

Jones PG, Guarino L, Jarvis A (2002) Computer tools for spatial analysis of plant genetic resources data: 2 FloraMap. Plant Genet Resour Newsl 130:6-10

Kala CP (2005) Current status of medicinal plants used by traditional vaidyas in Uttaranchal State of India. Ethnobotany Res App 3:267-278

Karachi M (1997) Growth and nutritive value of Lablab purpureus accessions in semi-arid Kenya. Trop Grass1 31:214-218

Kay DE (1979) Food legumes: crop and product digest no 3. Tropical Products Institute, London, $436 \mathrm{pp}$

Kehlenbeck K (2007) Rural homegardens in Central Sulawesi, Indonesia: an example for a sustainable agro-ecosystem? $\mathrm{PhD}$ thesis at Georg-August-Univ. Göttingen, Germany, 223 pp. Electronic Dissertations and Habilitations of University of Goettingen, Goettingen State and University Library [Online: http://webdoc.sub.gwdg.de/diss/2007/kehlenbeck/kehlenbeck. pdf]

Keller G (2004) African nightshade, eggplant, spiderflower et al. production and consumption of traditional vegetables in Tanzania from the farmers point of view. MSc thesis, Georg-August-Univ., Göttingen, Germany, $251 \mathrm{pp}$

Keller GD, Mndiga H, Maass BL (2006) Diversity and genetic erosion of traditional vegetables in Tanzania from the farmer's point of view. Plant Genet Resour 3:400-413

Konduri V, Godwin ID, Liu C (2000) Genetic mapping of the Lablab purpureus genome suggests the presence of 'cuckoo' gene(s) in this species. Theor Appl Genet 100(6):866-871

Kouyaté Z, Franzluebbers K, Juo ASR, Hossner LR (2000) Tillage, crop residue, legume rotation, and green manure effects on sorghum and millet yields in the semiarid tropics of Mali. Plant Soil 225:141-151

Krol M (1992) Changing homegardens in upland Java. The effects of changing social economic conditions on the use of Javanese homegardens: a case study in two villages in Gunung Kidul District, Java, Indonesia. Forestry/Nature Conservation Project, FONC Project Communication No. 1992-4, Yogyakarta, Indonesia

Kumar A, Ramakrishnan PS (1990) Energy flow through an Apatani village ecosystem of Arunachal Pradesh in northeast India. Hum Ecol 18(3):315-336

Lelei JJ, Onwonga RN, Freyer B (2009) Organic based nutrient management strategies: effect on soil nutrient availability and maize (Zea mays L.) performance in Njoro, Kenya. Afr J Agric Res 2:92-99

Levang P, de Foresta H (1991) Economic plants of Indonesia: a Latin, Indonesian, French and English dictionary of 728 species. ORSTOM und SEAMEO BIOTROP, Bogor, $180 \mathrm{pp}$

Liu CJ (1996) Genetic diversity and relationships among Lablab purpureus genotypes evaluated using RAPD markers. Euphytica 90:115-119

Liu CJ (1998) Lablab cv. Endurance. Plant Var J 11:26-27

Maass BL, Usongo MF (2007) Changes in seed characteristics during the domestication of the lablab bean (Lablab purpureus (L.) Sweet: Papilionoideae). Aust J Agric Res 58:9-19
Maass BL, Ayisi KK, Bopape PM, Usongo M, Pengelly BC (2003) Appropriate germplasm facilitates new interest in neglected crops-the case of Lablab purpureus in the Limpopo Province, South Africa. Int. workshop on underutilized plant species, 6-8 May 2003, Leipzig, Germany. CDROM produced by InWent, Leipzig-Zschortau, Germany. [Online 13.02.2008 from: http://www.underutilized-species. org/record_details.asp?id=140]

Maass BL, Jamnadass RH, Hanson J, Pengelly BC (2005) Determining sources of diversity in cultivated and wild Lablab purpureus related to provenance of germplasm using amplified fragment length polymorphism (AFLP). Genet Resour Crop Evol 52:683-695

Mahadevu P, Byre Gowda M (2005) Genetic improvement of Dolichos bean (Lablab purpureus (L.) Sweet) through use of exotic and indigenous germplasm. Indian J Plant Genet Resour 18:1

Makembe NET, Ndlovu LR (1996) Dolichos lablab (Lab lab purpureus cv. 'Rongai') as supplementary feed to maize stover for indigenous female goats in Zimbabwe. Small Rumin Res 21:31-36

Maundu PM, Ngugi GW, Kabuye CHS (1999) Traditional food plants of Kenya. National Museums of Kenya, English Press, Nairobi, $270 \mathrm{pp}$

Mir FUA, Rahman SML, Mesbahuddin Ahmed ASM, Quebedeaux B (2004) Agroforestry as it pertains to vegetable production in Bangladesh. J Agron 3(4):282-290

Mitra SK, Pathak PK (2009) Underutilized plant species: implications in homestead farming. In: Jaenicke H, Ganry J, HoeschleZeledon I, Kahane R (eds) Proc. int. symposium on underutilized plants for food security, nutrition, income and sustainable development. ISHS Acta Hort 806:107-113

MMPND (Searchable World Wide Web Multilingual Multiscript Plant Name Database) (2005) Sorting Lablab names. University of Melbourne, Australia, [Online 19.02.2008 from: http:/www. plantnames.unimelb.edu.au/Sorting/Lablab.html]

Mohan N, Aghora TS (2006) Collection and evaluation of Dolichos bean (Lablab purpureus [L.] Sweet) Germplasm in Tamil Nadu, India. Poster presented at Int. Conf. on Indigenous Vegetables and Legumes: Prospects for Fighting Poverty, Hunger and Malnutrition. 12-15 Dec. 2006, Patancheru, India. [Online 05.11.2007 from: www.ivs2006.org/PosterSession.pdf]

Momen RU, Huda SMS, Hossain MK, Khan BM (2006) Economics of the plant species used in homestead agroforestry on an offshore Sandwip island of Chittagong District, Bangladesh. J For Res 17(4):285-288

Morris JB (2009) Morphological and reproductive characterization in hyacinth bean, Lablab purpureus (L.) Sweet germplasm with clinically proven nutraceutical and pharmaceutical traits for use as a medicinal food. J Diet Suppl 6(3):263-279

Mubiru DN, Coyne MS (2009) Legume cover crops are more beneficial than natural fallows in minimally tilled Ugandan soils. Agron J 101(3):644-652

Muchow RC (1985) Phenology, seed yield and water use of grain legumes grown under different soil water regimes in a semi-arid tropical environment. Field Crops Res 11:81-97

Mugwira LM, Haque I (1993) Screening forage and browse legumes germplasm to nutrient stress: II. Tolerance of Lablab purpureus L. to acidity and low phosphorus in two acid soils. J Plant Nutr 16:37-50

Mureithi JG, Gachene CKK, Ojiem J (2003) The role of green manure legumes in smallholder farming systems in Kenya: the legume research network project. Tropical and Subtropical Agroecosystems $1: 57-70$

Murphy AM, Colucci PE (1999) A tropical forage solution to poor quality diets: a review of Lablab purpureus. Livestock Research 
for Rural Development 11(2) [Online 20.08.2008 from: http:// www.cipav.org.co/lrrd/lrrd11/2/colu112.htm]

Nahar K, Newaz MA (2005) Genetic variability, character association and path analysis in lablab bean (Lablab purpureus L.). Int J Sustain Agric Technol 1(6):35-40 [Online from: http://www. gscience.net/ijsat_issue6_35_40_december05.html]

Ngailo JA, Kaihura FBS, Baijukya FP, Kiwambo BJ (2003) Changes in land use and its impact on agricultural biodiversity in Arumeru, Tanzania. In: Kaihura F, Stocking M (eds) Agricultural biodiversity in smallholder farms of East Africa. United Nations University Press, Tokyo, pp 145-158

NIAS (National Institute of Agrobiological Sciences) (2009) Plant genetic resources databases, Tsukuba, Japan. [Online 11.11.2009 from: http://www.gene.affrc.go.jp/databases-plant_search_en.php]

NRC (National Research Council) (2006) Lablab. In: Lost crops of Africa, vol. II: vegetables. NRC, Washington DC, USA, pp 190-205

Nworgu FC, Ajayi FT (2005) Biomass, dry matter yield, proximate and mineral composition of forage legumes grown as early dry season feeds. Livestock Research for Rural Development 17(11) [Online 14.11.2007 from: http://cipav.org.co/lrrd/lrrd17/11/nwor17121.htm]

Nyambati EM, Sollenberger LE, Hiebsch CK, Rono SC (2006) Onfarm productivity of relay-cropped mucuna and lablab in smallholder crop-livestock systems in northwestern Kenya. J Sustain Agric 28(1):97-116

Nyende P, Delve RJ (2004) Farmer participatory evaluation of legume cover crop and biomass transfer technologies for soil fertility improvement using farmer criteria, preference ranking and logit regression analysis. Exp Agric 40:77-88

Odunze AC, Tarawali SA, de Haan NC, Akoueguon GE, Amadji AF, Schultze-Kraft R, Bawa GS (2004) Forage legumes for soil productivity enhancement and quality fodder production. J Food Agric Environ 2(2):201-209

Ojiem JO, Vanlauwe B, de Ridder N, Giller KE (2007) Niche-based assessment of contributions of legumes to the nitrogen economy of Western Kenya smallholder farms. Plant Soil 292:119-135

Patil P, Venkatesha SC, Ashok TH, Gowda TKS, Byre Gowda M (2009) Genetic diversity in field bean as revealed with AFLP markers. J Food Legumes 22(1):18-22

Peng YL, Wang XM, Li M, Tang CW (2001) A new extremely early variety of Dolichos lablab L. 'Xiangbiandou 1'. Acta Hort Sinica 28(5):480

Pengelly BC, Maass BL (2001) Lablab purpureus (L.) Sweet—diversity, potential use and determination of a core collection of this multipurpose tropical legume. Genet Resour Crop Evol 48:261-272

Peyre A, Guidal A, Wiersum KF, Bongers F (2006) Dynamics of homegarden structure and function in Kerala, India. Agrofor Syst 66(2):101-115

Piper CV, Morse WJ (1915) The bonavist, lablab or hyacinth bean. USDA, Washington DC, USA. USDA Bull 318:1-15

Rahman J, Newaz MA, Islam MS (2002) Combining ability analysis on edible pod yield in $\mathrm{F}_{2}$ diallel population of lablab bean (Lablab purpureus L.). J Agric Educ Technol 5(1 and 2):33-36

Rahman SA, Ogungbile AO (2006) Productivity of forage legumes intercropped with maize and their acceptability to livestock in the savanna zone of Nigeria. Trop Sci 46(4):198-200

Ramasamy P, Balasubramanian M, Gnanam R, Rangasamy P (1990) Co 11 avarai (Lablab purpureus var. typicus (L.) Sweet), a new short duration photoinsensitive variety for Tamil Nadu. Madras Agric J 77(3-4):121-124

Ramme S (2002) An ecogeographic survey of Lablab purpureus (L.) Sweet and six related Dolichos species from Africa. MSc thesis, Georg-August-Univ., Göttingen, Germany, 134 pp

Rangaswami Ayyangar GN, Krishnan Nambiar KK (1935) Studies in Dolichos lablab (Roxb.) and (L.) - the Indian field and garden bean. II. Proc Ind Acad Sci 2(1):74-79
Rashid MA, Tauhidur Rahman M, Shahadad Hussain M, Motiur Rahaman M (2007) Indigenous vegetables in Bangladesh. In: Chadha ML, Kuo G, Gowda CLL (eds) Proc. 1st int. conference on indigenous vegetables and legumes - prospectus for fighting poverty, hunger and malnutrition. ISHS Acta Hort 752:397-400

Rivals F (1953) Le dolique d'Egypte ou lablab. 2. Sous-espèce, bases de classement des variétés, variabilité des conditions de floraison, intérêt agricole des variétés de jours courts. Rev Int Bot Appl Agric Trop 33:518-537

Rokhsana A, Ahamed F, Kabir MS, Shamsuddula AM, Amin MW (2006) Early bean marketing system in some selected areas of Bangladesh. Int J Sustain Agric Technol 2(2):58-65

Sakala WD, Kumwenda JDT, Saka AR (2004) The potential of green manures to increase soil fertility and maize yields in Malawi. In: Bationo A (ed) Managing nutrient cycles to sustain soil fertility in subSaharan Africa, chapter 26. Academy Science, Nairobi, pp 373-384

Sankaran M, Singh NP, Jai Prakash (2007) Genetic resources of underutilized horticultural crops in Tripura. In: Peter KV (ed) Underutilized and underexploited horticultural crops, chapter 1. New India Publishing Agency, New Delhi, pp 1-20

Schaaffhausen RV (1963) Dolichos lablab or hyacinth bean: its uses for feed, food and soil improvement. Econ Bot 17:146-153

Shehu Y, Alhassan WS, Pal UR, Phillips CJC (2001) The effects of sowing date on the growth and nutritive value of Lablab purpureus. J Agron Crop Sci 186:21-29

Shivashankar G, Kulkarni RS (1989) Lablab purpureus. In: van der Maesen LJG, Sadikin Somaatmadja (eds) Plant resources of Southeast Asia, no. 1, Pulses. Pudoc, Wageningen, The Netherlands, pp 48-50

Singh BB, Matsui T (2002) Cowpea varieties for drought tolerance. In: Fatokun CA, Tarawali SA, Singh BB, Kormawa PM, Tamò M (eds) Challenges and opportunities for enhancing sustainable cowpea production. Proc. World Cowpea Conference III, International Institute of Tropical Agriculture (IITA), Ibadan, Nigeria, 4-8 Sept. 2000. IITA, Ibadan, Nigeria, pp 278-287

Smith GR, Rouquette FM Jr, Pemberton IJ (2008) Registration of 'Rio Verde' lablab. J Plant Registrations 2(1):15

Subagio A, Morita N (2008) Effects of protein isolate from hyacinth beans (Lablab purpureus (L.) Sweet) seeds on cake characteristics. Food Sci Technol Res 14(1):12-17

Subedi A, Suwal R, Gautam R, Sunwar S, Pratap Shrestha P (2006) Status and composition of plant genetic diversity in Nepalese home gardens. In: Gautam R, Sthapit BR, Shrestha PK (eds) Home Gardens in Nepal: Proc. workshop on Enhancing the contribution of home garden to on-farm management of plant genetic resources and to improve the livelihoods of Nepalese farmers: lessons learned and policy implications, 6-7 August 2004, Pokhara, Nepal. LI-BIRD, Bioversity International and SDC, Rome, Italy, pp 72-83

Sujithra M, Srinivasan S, Sudhakar P (2009) Molecular diversity in certain genotypes of field bean (Lablab purpureus var. lignosus Medikus) in relation to pod insect pest complex. Current Biotica 3(2):256-263

Sultana N, Ozaki Y, Okubo H (2000) The use of RAPD markers in lablab bean (Lablab purpureus (L.) Sweet) phylogeny. Bull Inst Trop Agric Kyushu Univ 23:45-51

Sultana N, Ozaki Y, Okubo H (2001) Early identification of determinate growth habit in lablab bean (Lablab purpureus (L.) Sweet). J Fac Agric Kyushu Univ 46(1):31-38

Sunwar S, Thornström C-G, Subedi A, Bystrom M (2006) Home gardens in western Nepal: opportunities and challenges for onfarm management of agrobiodiversity. Biodiver Conserv $15: 4211-4238$

Tefera TA (2006) Towards improved vegetable use and conservation of cowpea (Vigna unguiculata) and lablab (Lablab purpureus): 
agronomic and participatory evaluation in northeastern Tanzania and genetic diversity study. Cuvillier Verlag, Goettingen, $214 \mathrm{pp}$

Thornton PK, Kruska RL, Henninger N, Kristjanson PM, Reid RS, Atieno F, Odero AN, Ndegwa T (2002) Mapping poverty and livestock in the developing world. International Livestock Research Institute (ILRI), Nairobi, 124 pp

Tian Z, Wang S, Wang W, Liu L (2005) Study on the diversity of germplasm resources of Dolichos lablab L. Natural Science J Hainan Univ 23(1):53-60

Uddin MB, Mukul SA (2007) Improving forest dependent livelihoods through NTFPs and home gardens: a case study from Satchari National Park. In: Fox J, Bushley BR, Dutt S, Quazi SA (eds) Making conservation work: lining rural livelihoods and protected areas in Bangladesh. East-West Center, Honolulu, and Nishorgo Program of the Bangladesh Forest Department Dhaka, Bangladesh, pp 13-35

Veerabadhiran P, Muthiah AR, Subbalakshmi B, Nadarajan N, Raveendara TS (2001) Ultra short duration vegetable hyacinth bean (Lablab purpureus var. typicus) - A wonder. Poster presented at Int. Conf. on Indigenous Vegetables and Legumes: Prospects for Fighting Poverty, Hunger and Malnutrition. 12-15 Dec. 2006, Patancheru, India. [Online 05.11.2007 from: www.ivs2006.org/PosterSession.pdf]

Venkatesha SC, Byre Gowda M, Mahadevu P, Mohan Rao A, Kim D-J, Ellis THN, Knox MR (2007) Genetic diversity within Lablab purpureus and the transferability of gene-specific markers from a range of legume species. Plant Genet Resour 5:154-171

Verdcourt B (1970) Lablab Adans. In: Studies in the LeguminosaePapilionoideae III. Kew Bull 24:409-411

Verdcourt B (1979) Lablab. In: A manual of New Guinea legumes. Botany Bull 11:537
VIR (N.I. Vavilov All-Russian Scientific Research Institute of Plant Industry) (2009) Passport data of germplasm collections, St. Petersburg, Russia. [Online 11.11.2009 from: http://www.vir.nw. $\mathrm{ru} / \mathrm{data} / \mathrm{dbf} . \mathrm{htm}]$

Wang ML, Gillaspie AG, Newman ML, Dean RE, Pittman RN, Morris JB, Pederson GA (2004) Transfer of simple sequence repeat (SSR) markers across the legume family for germplasm characterization and evaluation. Plant Genet Resour 2(2):107-119

Wang ML, Morris JB, Barkley NA, Dean RE, Jenkins TM, Pederson GA (2007) Evaluation of genetic diversity of the USDA Lablab purpureus germplasm collection using simple sequence repeat markers. J Hortic Sci Biotechnol 82(4):571-578

Westphal E (1974) Pulses in Ethiopia, their taxonomy and agricultural significance. Center for Agricultural Publishing and Documentation, Wageningen, $263 \mathrm{pp}$

Whitbread AM, Pengelly BC (eds) (2004) Tropical legumes for sustainable farming systems in southern Africa and Australia. ACIAR Proc. no. 115, Canberra, Australia, 180 pp

Wortmann CS, McIntyre BD, Kaizzi CK (2000) Annual soil improving legumes: agronomic effectiveness, nutrient uptake, nitrogen fixation and water use. Field Crops Res 68:75-83

Xi Z, Tang H (2006) Xiangbiandous Dolichos lablab RAPD fingerprint construction. Journal of Hunan University of Arts and Science (Natural Science)

Yadav RK, Yadav DS, Rai N, Patel KK (2003) Prospects of horticulture in north eastern region. ENVIS Bull Himal Ecol 11 (2): $10-25$

Yuan J, Yang R, Wu T (2009) Bayesian mapping QTL for fruit and growth phenological traits in Lablab purpureus (L.) Sweet. Afr J Biotechnol 8(2):167-175 